DOI: 10.19195/0137-1150.163.49

\author{
MARTINA SALHIOVÁ \\ Masarykova univerzita v Brně, Republika Czeska \\ 9524@mail.muni.cz
}

\title{
Stárnou pohádkové bytosti v současné české literární tvorbě pro děti a mládež?
}

V současné české literatuře pro děti a mládež se projevuje několik výrazných tendencí. Je ovlivněna tzv. „literaturou otázek”, která předpokládá různé interpretace za spoluúčasti recipienta. Dochází k narušení pomyslné hranice mezi literaturou pro děti a pro dospělé čtenáře, díla začínají směřovat $\mathrm{k}$ univerzálnímu recipientovi (tzv. „otevřenost díla”). Mění se role vypravěče, žánry a narační styly se vzájemně prolínají, pronikají závažná témata: holokaust, obraz handicapovaného hrdiny, tematika etnická (romská, vietnamská), fenomén outsiderství, nevyléčitelné nemoci, sebevraždy, stáří a smrti. Tento jev bývá označován ruským termínem vzroslenije, francouzským adultisation nebo termínem Mileny Šubrtové „filozofizace literatury pro děti a mládež” ${ }^{1}$, který není spojen pouze s binární opozicí dětství - dospělost jako předchozí dva termíny, ale hlouběji vystihuje podstatu problému.

Literární realizace postojů ke stáří se tedy nevyhýbá ani tvorbě pro děti a mládež. Jakým způsobem je zachycen proces stárnutí, nebo naopak — omládnutí, nového zrození pohádkové či legendární bytosti si doložíme na próze s dětským hrdinou Dračí polévka ${ }^{2}$, v pohádkové trilogii Lichožrouti ${ }^{3}$, kde se na konec života připravují pohádkové bytosti, a v pohádkové knize František z kaštanu, Anež-

${ }^{1}$ M. Šubrtová, Filozofizace literatury pro děti a mládež. Nad prózami D. Fischerové, I. Procházkové a J. Knitlové, [w:] S. Urbanová et al., Sedm klíču k otevřeni literatury pro děti a mládež 90. let XX. století. Reflexe české tvorby a recepce, Praha 2004, s. 145-161.

2 A. Ježková, Drači polévka, il. IKKARIN, Praha 2011, 96 s.

3 P. Šrut, Lichožrouti, il. G. Miklínová, 2. vyd., Praha 2012, 232 s; P. Šrut, Lichožrouti na$v z ̌ d y$, il. G. Miklínová, Praha-Litomyšl 2013, 232 s; P. Šrut, Lichožrouti se vracejí, il. G. Miklínová, Praha a Litomyšl 2010, 184 s. 
ka ze slunečnic ${ }^{4}$ o cykličnosti života $\mathrm{v}$ přírodě. Autorské (literární) pohádky na rozdíl od lidových pracují s postavami odlišně. Mizí časová a místní neurčitost, postavy se pohybují v reálném světě (v Lichožroutech pohádkoví hrdinové zažívají dobrodružství v Praze i v džungli Tanzanie), dále autorské pohádky odrážejí společenskou realitu a civilizační pokrok (v pohádce František z kaštanu, Anežka ze slunečnic opouští malá Anežka rodné pole, aby nezahynula při sklizni úrody rozdrcena kombajnem). Pohádky i legendy se zbavují mysticismu a osudovosti, postavy se přibližují reálnému světu za pomoci rozmanitých autobiografických prvků (v Lichožroutech se scházejí dvě postavy za účelem vytvoření nové pohádkové knihy — jeden spisovatel, který toho má už hodně za sebou, a jedna ilustrátorka, která toho má ještě dost před sebou).

Autorské pohádky se často přibližují jinému literárnímu žánru: fantasy, pověsti, povídce, románu, anekdotickému vyprávění, př́iběhu ze života dětí a naopak; tyto beletristické žánry mohou obsahovat pohádkové motivy nebo postupy (Drači polévka v sobě zahrnuje starou asijskou legendu, dědeček hlavního hrdiny je samotný Dračí král, který na sebe vzal lidskou podobu, aby mohl na určitý čas v neúplné rodině zastoupit svého nepř́itomného syna ${ }^{5}$ ).

Za další rys literárních pohádek můžeme považovat psychologické vyzrávání postav. Mladý lichožrout Hihlík dospívá, odmítá lidskou pomoc, kterou jako dospělý jedinec nepotřebuje. Skř́itek František si uvědomuje vlastní pochybení, snaží se o nápravu a odchází hledat Anežku, se kterou se však v této životní podobě nesetká. Vietnamský chlapec Long odmítá svou totožnost, nechává si odbarvit vlasy na blond, což vyprovokuje skupinu skinheadů a zároveň přináší trpké poznání sebe sama.

Důležitou úlohu ve výše zmíněných dílech hraje popis stárnutí/dozrávání a postoj mladých postav (především vnuků) $\mathrm{k}$ seniorům, u kterých dochází k novému pohledu na svět, ale i ke značnému poklesu výkonnosti a ke změně sociální role (prarodičovství, ukončení pracovního poměru, odchod do důchodu — např. přestávají si sami obstarávat potravu — krást ponožky, ruší provoz stánku na tržnici). Popis stárnoucího člověka dobře vystihl Jean Améry: „,[...] ř́ká se, že starý člověk má život za sebou, avšak tento život, jenž již není reálně žit, není ničím jiným než nastřádaným časem, prožitým, vlastně odžitým." 6

Z hlediska psychologie se stala významnou přepracovaná teorie Erika Eriksona (1902-1994), ve které rozdělil lidský život do devíti stádií, v nichž jedinec úspěšně či neúspěšně překonává přirozené krize lidského vývoje. Nás zajímají dvě poslední období: stáří (integrita ega se staví proti pochybování, strachu ze smrti, zoufalství z nenaplněného života, opovržení; klade se důraz na lidstvo, moudrost, vyrovnání se s bilancí vlastního života i blížící se smrtí) a pokročilé stáří (základní důvěra a pokora stojí proti základní nedůvěře, sebeodmítnutí,

\footnotetext{
${ }^{4}$ R. Malý, František z kaštanu, Anežka ze slunečnic, il. G. Miklínová, Praha 2006, $60 \mathrm{~s}$.

${ }^{5}$ Viz např. pohádka Praotec Lac Long Quan v knize Drači král. Vietnamské pohádky, přel. P. Millerová, Praha-Podlesí 2001, s. 35-41.

${ }^{6}$ J. Améry, O stárnutí. Revolta a rezignace, Praha 2008, s. 31.
} 
vyostřenému sledování vlastního těla). Za nejvyšší stav, kterého může člověk dosáhnout, je považováno pochopení řádu věcí, spokojenost, vyrovnanost a tzv. gerotranscendence — přijetí vědomí konečnosti života, hluboká moudrost. ${ }^{7}$ Podle Jána Šrama staří lidé pohlížejí a dohlížejí rozumněji na společenské události, střeží všeobecnou společenskou pamět', dokážou lépe posoudit lidské ideály a hodnoty, regulují a usměrňují společenské soužití. ${ }^{8}$

Autorka první sledované knihy Alena Ježková (nar. 1966), česká novinářka, nezávislá konzultanta v oblasti komunikace, editorka a spisovatelka knih pro děti a mládež, se zabývá především tématem Prahy, např. Praha babka měst (2002), 77 pražských legend (2006), Strážci pražských ulic (2006) a Prahou kráčí lev (2008).

Drači polévka je př́během o úctě a toleranci, a to nejen mezi českou a vietnamskou komunitou v Praze, ale také mezi generacemi. Při obtížné komunikaci chlapce s vlastními rodiči vypomáhá dědeček. Jeho př́iběhy, vtipy, pohádky (např. o velké rýži, která $\mathrm{k}$ lidem chodila sama $)^{9} \mathrm{i}$ otřepané písně naučené $\mathrm{z}$ vietnamské televize se stávají nedílnou součástí chlapcova dětství. Avšak dědeček není obyčejný starý muž, patří do rodu draků, a tak se stáří prolíná s legendou o nesmrtelnosti: „Daleko ve východní zemi, hluboko na dně vodní ř́řš žil ve svém paláci Lac Long Quan, Dračí král. Měl spoustu neobyčejných schopností. Uměl chodit po vodě, létat vzduchem, brát na sebe různou podobu a všelijak čarovat."10 Kvůli vnukovi se proměnil ve starého nahluchlého prodavače vietnamských jídel a opustil milovaný domov.

Long (Drak) neboli Lád’a, dvanáctiletý chlapec žijící s matkou v Praze, hraje stínohru dvou velmi odlišných životů — českého a vietnamského. Stejně jako jeho sestřenice neumí vietnamsky číst a psát, je velmi ovlivněn českou kulturou a životem na rozsáhlém sídlišti. Touží po odchodu ze země, kde zůstane provždy cizincem. Zároveň poznává, že dospívání se nedá považovat za jednoduchý proces. Kromě nalezení první lásky a vlastního otce ztrácí mnohé iluze i prátele — přichází o věrného průvodce dětstvím — dědečka, který jej zasvětil do východní filozofie, především do myšlenek Konfucia. Když dostane jako dárek na rozloučenou staré ohmatané spisy, pochopí, že se musí vlastní kulturu doučit, aby se stal celým člověkem.

Chlapec oceňuje, že starý muž zaujal dědovskou roli tak vynikajícím způsobem. Domnívá se však, že se nejedná o vlastního dědečka, ale o muže, který se k němu a matce připojil náhodně cestou do Čech. Neví nic o jeho zástupné roli, ve které mu nahrazuje otce — jednoho ze sta dračích synů. „S dědou je totiž všechno tak i tak: př́ísné i rozmařilé, rozumné i praštěné, záhadné i jasné." ${ }^{11}$ Dědeček, přestože je popisován jako velmi starý muž s fyzicky zpomalenými reflexy,

${ }^{7}$ I. Stuchlíková, Dospělost, 2006, http://home.pf.jcu.cz/ stuchl/Dospelost.doc [cit. 9. května 2015].

\footnotetext{
8 J. Šramo, Př́iprava na stáři, Praha 2012, s. 29-30.

${ }^{9}$ Viz např. pohádka Bůh rýže v knize Drači král..., s. 23-25.

${ }^{10}$ A. Ježková, op. cit., s. 7.

${ }^{11}$ Ibidem, s. 21.
} 
zhoršeným sluchem a zdravím, patří mezi vážené osobnosti pražské vietnamské komunity. Není to jen díky jeho věhlasné dračí polévce, kterou prodává v tržnici, ale především díky vitalitě, životnímu postoji a nesmírným znalostem východního myšlení i poezie. Také malý Long, chce-li se zapojit do dospělé společnosti, podstupuje iniciační proces, musí dokázat interpretovat verše dávného básníka: „Hladina moře zrcadlí nebesa. Svět je jen dračí sen."12 Po útěku z domova právě v nich nalézá útěchu a naději a poprvé spatřuje jejich hloubku.

Po zrušení stánku ve vietnamské tržnici dědeček touží po návratu domů, chce navázat staré sociální kontakty. Long si bez jeho ranního chrchlání, dupaného tai-či, bez dračí polévky a kulaté hlavy skloněné nad oltářem předků neumí představit následující život. Dědečkovo stáří výrazně dotvářelo chlapcovo dětství. Stáří je popisováno jako běžná součást vietnamské rodiny:

Dědovo vstávání je složitý obřad. Nejdřív to z kuchyně vrže, jak se převaluje na pérovém gauči. Pak děda mohutně chrchlá, protože si sedá a vstává, potom funí, heká a měkce dupe, protože cvičí tai-či. Děda je sice dost starý, ale tai-či cvičí krásně. Polohu hada, jeřába, tygra, opice a leoparda. ${ }^{13}$

Long vyčítá dědovi touhu po domově a chce zapomenout vše, co jej naučil. Dědeček mu odhaluje svou pravou „dračí” podobu: dívá se na vnuka očima něžnýma jako perletová křídla můr, roztahuje obrovská kožnatá křídla, silným ocasem buší do odpadků a špíny. Zdůrazňuje, že jedinečný životní běh nemusí být přijímán jako poslední možnost života. Dává dračímu vnukovi ponaučení o lidském životě, který se podobá dračí polévce, kterou jej učil vařit:

Nejdřív musíš být trpělivý, čekat, až se všechno dobře uvaří, aby to mělo správnou sílu. To může trvat velmi dlouho, a navíc tě může výsledná chut' překvapit. Vždycky ale můžeš něco přidat, něco ubrat. To je na tobě. Je to přece tvoje polévka! Nejprve musí chutnat tobě, a pak ji můžeš nabízet i jiným. ${ }^{14}$

Znovu se projevuje dědečkův smysl pro humor, když sděluje vnukovi vlastní moudrost a varování, aby se ve své vlastní polévce nenechal uvařit. Poukazuje na to, že i loučení a rozchod blízkých bytostí nepostrádá smysl a že shledání se v dalším životě je možné, záleží jen na nás.

Český spisovatel, básník a překladatel Pavel Šrut (nar. 1940) využil běžného problému lidských domácností — mizení ponožek — jako základního tématu pohádkové trilogie s neobvyklým názvem Lichožrouti (2008), Lichožrouti se vracejí (2010) a Lichožrouti navždy (2013). Dílo přináší pohled dospělé osoby do tajemného fantaskního světa, který je podobný tomu dětskému. Pohádka zaujme rozsahem, proto by se dala nazvat pohádkovým románem, či ponožkožroutí ságou. Vyskytují se zde tři staré pohádkové postavy: ochránce a pečovatel (dědeček hlavní postavy — mladého Hihlíka), posel míru (letitý Háro, člen mafiánského gangu Dolního města) a poskytovatel rady (indický myslitel Mahavišna).

12 Ibidem, s. 31.
13 Ibidem, s. 13.
14 Ibidem, s. 73. 
Hihlíkův dědeček velmi omezil sociální kontakty, nestýká se ani s vlastním synem, bývalým mafiánem Tulamorem seniorem. Žije osaměle s vnoučkem za zdí lidského bytu hudebníka Egona Vavřince. Jelikož má sníženou mobilitu a dosáhl pokročilého věku, ve kterém cítí blížící se konec, je závislý na pomoci svého mladičkého vnuka, jehož vychovával k ochotě, slušnosti a zdvořilosti. Snažil se napravit chyby, které způsobil při výchově dvou synů: „Hrozně si přál, aby z něho vyrostl spokojený lichožrout, který povede spokojený lichožroutí život, vezme si spokojenou lichožroutí ženu, s kterou vychová pár spokojených dětí, a když se naplní jeho lichožroutí čas, spokojeně se vytratí." 15 Dědeček usiluje o pochopení řádu světa i o shrnutí všech předchozích životních etap — plně prožil svůj život, splnil předcházející vývojové úkoly, s uspokojením se dívá nazpět a zažívá pocit smysluplnosti v pohádkovém světě.

Důležitou úlohu hrají př́írodní živly: voda, jež očištuje a obrozuje, a vítr či průvan, jenž posílá lichožrouty na cestu poslední. Autor ji popisuje jako tzv. hezkou smrt — postupné vytrácení se: „Život a smrt si podávají ruce. Na rozdíl od lidí vlastně neumírají. Vytrácejí se v povětří. Mizí ze světa. Ale kam? To je záhada. Ale ještě větší záhada je, jak lichožrouti na svět přicházejí." ${ }^{16}$ Dědečka přestává vše bolet, jen se jemně usmívá. Rád by ochutnal poslední novinku ponožky ve tvaru rukavice, ale čas již vypršel. Přijímá vědomí konečnosti života — dosahuje celkové životní spokojenosti, vyrovnanosti. Za hudby pana domácího se mizí jako bílý stín do krásného pražského povětří.

Háro na rozdíl od Hihlíkova dědečka nežije osaměle, ale uprostřed kojotího gangu. Přestože se s jejich názory zásadně rozchází — je zastáncem lásky, míru a přátelství, všichni členové jej ctí jako nedotknutelného, jako strážce tajemství gangu — starého bojového rituálu divokých lichožroutů, který se dávno nepoužívá, ale zůstal v paměti jako poslední řešení sporů o nadvládu nad Dolním městem:

Uměl zpaměti slavnostní jazyk celého obřadu, i když se mu jeho krutost př́čila. Čtyřri Kojoti přinesli prošoupaný rudý koberec a natáhli ho na podlahu. Další čtyři Kojoti položili na koberec železnou skřínku. Háro ji důstojně otevřel. V té skř́ńnce bylo něco, co vypadalo jako obrovská černá punčocha [...]. „Vstupte do tmy a bijte se!” prohlásil Háro přiškrceným hlasem. ${ }^{17}$

Háro se snaží svůj nastřádaný čas předat mladší generaci, vrozenou autoritou nakonec usmiřuje nepřátelské gangy a vyhlašuje mír navždy. Vůdčí osobnosti lichožroutů změní toto heslo na nové - Lichožrouti navždy, což připomíná i název třetího dílu.

Indický lichožrout Mahavišna žije osamoceně ve skromném př́istřešku uprostřed africké džungle. I když se ocitá v úplné, ale dobrovolné izolaci, nezapomíná na problémy lichožroutů (lidstva) a vymýšlí metodu holobřišního dýchání,

\footnotetext{
15 P. Šrut, Lichožrouti..., s. 144.

16 P. Šrut, Lichožrouti navždy..., s. 147.

17 Ibidem, s. 47.
} 
díky níž by se mohlo jíst bez jídla a pít bez vody. Starý moudrý jogín učí i mladého lichožrouta Ramíka sycení se vzduchem, avšak neúspěšně. Mahavišna postupně docílil odklonu od zaujetí vnějším materiálním světem, objevil sám sebe a hledal a našel smysl svého predlouhého života, dosahuje tzv. stavu gerotranscendece. $Z$ jeho př́bytku dýchá posvátno, úcta a velebnost. Ind snížil množství vydávané i přijímané energie na minimum, projevuje se u něj menší rychlost zpracování informací, ale ne pokles schopnosti logického uvažování a učení se. Často se zdá, že usíná únavou, ale on zatím usilovně přemýšlí.

Radek Malý (nar. 1977), olomoucký prozaik, básník, překladatel, publicista, autor slabikářů, abecedářůn, napsal pro děti sbírky veršů Kam až smí smích (2009), Listonoš vitr (2011), Moře slané vody (2014) a pohádkový př́iběh František z kaštanu, Anežka ze slunečnic (2006), který by se dal zařadit do imaginativní linie českých pohádek. ${ }^{18}$ Jedná se o dvojí př́iběh o vzniku přátelství, putování, bloudění, sžívání se, rozcházení se a hledání se, který začíná úvodní básní, jež naznačuje téma celého prríběhu:

Někdo se bojí říci Tma

tak řekne Den, co zavřel oči

Někdo se bojí říci Nic

tak řekne To Bůh Zemí točí

Někdo se bojí říci Smrt

tak řekne Vracíme se domů

Někdo se bojí

a věří tomu. ${ }^{19}$

Zdůrazněná slova (Tma a Den, Nic a Bůh, Smrt a Vracíme se) nestojí v úplné opozici, vše je neodmyslitelně propojeno v př́rodním koloběhu. Přestože v celé knize téměř není zmíněno slovo „stáří”, nese se celá kniha v jeho duchu. Stáŕí je zpodobněno metaforicky jako podzim života, po kterém už nic nepřichází, anebo je tomu jinak? „Stromy byly zesláblé a stahovaly mízu do kořenů. Poslední listy opouštěly mokré větve, jako opouštíme někoho, o kom víme, že se s ním nevidíme naposledy." 20

Skřítci-semínka jednoho podzimního dne odcházejí z rodných míst, náhodně se setkávají a společně hledají nový domov. Tvořivý František, zrozený z kaštanové slupky na malém nádraží, a odvážná Anežka, vylíhnutá ze slunečnicového semínka na rozzářeném poli poblíž nádraží, přečkávají v podzemní noře určité období, rozcházejí se a pak zahynou — mění se v jiný projev života — ve strom

18 Podle dělení Jaroslava Tomana. J. Toman, Česká autorská pohádka devadesátých let 20. století, [w:] Cesty současné literatury pro děti a mládež. Tradice - inovace, ed. J. Poláček, Slavkov u Brna 2003, s. 47-53. Díky vloženému příběhu by pohádka mohla patřit i mezi filozofující autorské pohádky.

${ }^{19}$ R. Malý, op. cit.

${ }^{20}$ Ibidem, s. 61. 
a v jednoletou rostlinu. V koloběhu skř́tkovského života se zdá starým ten, kdo zažil alespoň jedno zimní období. Zkušená myšice vypráví motýlům o přízemních mrazících, kteří zaškrtí vše živé. Nedůvěřiví motýli druhého dne zmizí. Milena Šubrtová, zabývající se tematikou smrti v dětské literatuře, napsala:

Proměnlivá atmosféra podzimní přírody, zachycená v působivých synestéziích a propojená s plastickými obrazy odkvétání, dozrávání, uvadání, tlení, není jen kulisou, ale př́mým aktérem vyprávění o životním koloběhu. František s Anežkou jsou součástí prŕírody — se stejnou přirozeností, s jakou se v ní pohybovali, se jí i odevzdávají. ${ }^{21}$

Vše začalo jedné větrné noci uprostř̌ed záríí, kdy ale celý příběh končí? Má vůbec konec? Setkají se dva přátelé, i když se každý z nich ocitá v jiném světě? Slunečnice s podzimem zahyne, aby se znovu narodila na jaře. Strom stojící poblíž je věrným pozorovatelem jejích přeměn.

[...] a tak si málokdo všímal toho, co vyrostlo na jedné mezi. Dozrávala tam slunečnice. Veliká a žlutozlatá, s hlavou skloněnou, a hvízdala si do vánku. A kdo by se podíval blíž, viděl by, že kousek vedle ní zapustil kořínky stromek. Zatím nedorostlý, ale jednou z něj bude — však vy víte co. Jírovec mad’al, po latinsku Aesculus hippocastanum. ${ }^{22}$

Imaginární bytosti v současné české tvorbě pro děti a mládež nejen stárnou a umírají jako skuteční lidé (Hihlíkův dědeček), ale i znovu ožívají (cyklus jednoleté rostliny), omlazují se a mění v nesmrtelný mýtus (Dračí král). Ve všech výše zmíněných knihách se staré pohádkové nebo legendární postavy úspěšně vyrovnaly s krizí typickou pro závěrečné období života, u postav Hára a Mahavišny to není pouhá spokojenost a vyrovnanost, nýbrž spění do vyššího stavu tzv. gerotran scendence. Smrt je plně respektovaná, netabuizovaná, přirozená součást (nebo vrchol) života. Výše zmínění autoři chtěli naznačit, že není tř̌eba $\mathrm{v}$ životě vše poznat, ale určité tajemství je lepší ponechat neodhalené (u Radka Malého např́íklad tajemství života schovaného v krtčí truhle). Žádná z postav nedosahuje stavu zoufalství, nikdo není neštastný, agresivní ani apatický. Naopak stávají se výzvou či vzorem mladým čtenářům. ${ }^{23}$

\section{Bibliografie}

Améry J., O stárnutí. Revolta a rezignace, Praha 2008.

Ježková A., Drači polévka, il. IKKARIN, Praha 2011.

Malý R., František z kaštanu, Anežka ze slunečnic, il. G. Miklínová, Praha 2006.

Praotec Lac Long Quan v knize Drači král. Vietnamské pohádky, přel. P. Millerová, Praha-Podlesí 2001.

Šramo J., Př́iprava na stáří, Praha 2012.

Šrut P., Lichožrouti, il. G. Miklínová, 2. vyd., Praha 2012.

${ }^{21}$ M. Šubrtová, Tematika smrti v české a světové próze pro děti a mládež, Brno 2007, s. 70.

22 R. Malý, op. cit., s. 59.

${ }^{23}$ Studie vznikla v rámci specifického výzkumu Ústavu české literatury a knihovnictví FF MU v Brně, kód MUNI/A/1167/2014. 
Šrut P., Lichožrouti na vždy, il. G. Miklínová, Praha-Litomyšl 2013.

Šrut P., Lichožrouti se vracejí, il. G. Miklínová, Praha a Litomyšl 2010.

Stuchlíková I., Dospělost, 2006, http://home.pf.jcu.cz/ stuchl/Dospelost.doc [cit. 9. května 2015].

Šubrtová M., Filozofizace literatury pro děti a mládež. Nad prózami D. Fischerové, I. Procházkové a J. Knitlové, [w:] S. Urbanová et al., Sedm kličů k otevřeni literatury pro děti a mládež 90. let XX. století. Reflexe české tvorby a recepce, Praha 2004, s. 145-161.

Šubrtová M., Tematika smrti v české a světové próze pro děti a mládež, Brno 2007.

Toman J., Česká autorská pohádka devadesátých let 20. století, [w:] Cesty současné literatury pro děti a mládež. Tradice - inovace, ed. J. Poláček, Slavkov u Brna 2003.

\section{Do the fairytale creatures grow old in contemporary Czech literature for children and youth?}

\section{Summary}

The literary creation for children and youth does not avoid the literary realizations of attitudes towards old age. In this article, we will introduce three diverse ways to capture the aging process, but also the rejuvenation of the mythical creatures. In the prose with a child hero Drači polévka, the Vietnamese grandfather was reborn as a lush dragon, in the fairy tale Lichožrouti, three different fairytale creatures are preparing for the end of their lives and in the book for children František z kaštanu, Anežka ze slunečnic, a metaphor of autumn is used to describe the cyclicality of the life in nature. Although the mentioned books are dissimilar, the description of old or aging persons is carried in the positive note, they become a pattern for little readers.

Keywords: literary fairy tale, prose with a child hero, old age, death, rebirth

\section{Остаряват ли приказните същества в съвременните чешки произведения за деца и юноши?}

Резюме

Дори в литературата за деца и юноши не отсъстват литературни реализации на отношението към старостта. В тази статия ще бъдат представени три различни начина за улавяне на процеса на стареене, но и подмладяване на митични същества. В прозата с дете герой Drači polévka виетнамски дядо се преражда в буен дракон, в приказката Lichožrouti трима различни приказни герои се подготвят за края на живота си, а в книгата за деца František z kaštanu, Anežka ze slunečnic използва метафората на есента, описваща цикличността на живота в природата. Въпреки че споменатите книги са много различни, описанието на стари или застаряващи лица се извьршва в положителен тон, те се преврьщат в модел на малките читатели.

Ключови думи: литературна приказка, проза с дете герой, старост, смърт, прераждане 